\title{
DIVIDEND PAYOUT RATIO DAN FAKTOR YANG MEMPENGARUHINYA PADA PERUSAHAAN MAKANAN DAN MINUMAN DI BURSA EFEK INDONESIA
}

\author{
TITA DEITIANA \\ STEVEN YAP \\ ERSANIA \\ Trisakti School of Management, Jl. Kyai Tapa No. 20, Grogol, Jakarta, Indonesia \\ tita@stietrisakti.ac.id, vimala@cbn.net.id
}

\begin{abstract}
This study aims to examine the factors that affect the Dividend Payout Ratio in food and beverage companies listed on the Indonesia Stock Exchange for the period 2011-2018. The research method used is purposive sampling in the sample collection technique, there are 7 companies that meet the criteria. In this study, it was analyzed using descriptive statistics and panel data regression methods with a fixed effect model to test the hypothesis. This research is processed using eviews 9 software. The results of this study Return on Asset, Current Ratio, Collateralized Asset do not have an influence on the Dividend Payout Ratio, but Debt To Equity Ratio, Firm Size have an influence on the Dividend Payout Ratio.
\end{abstract}

Keywords: Dividend payout ratio, return on asset, current ratio, debt to equity ratio, firm size, collateralized asset

Abstrak: Penelitian ini bertujuan untuk menguji faktor yang mempengaruhi Dividend Payout Ratio pada perusahaan makanan dan minuman yang terdaftar di Bursa Efek Indonesia periode 2011-2018. Metode penelitian yang digunakan adalah purposive sampling dalam teknik pengumpulan sampel, terdapat 7 perusahaan yang memenuhi kriteria. Pada penelitian ini dianalisis menggunakan statistik deskriptif dan metode regresi data panel dengan model fixed effect untuk menguji hipotesis. Penelitian ini diolah menggunakan software eviews 9 . Hasil dari penelitian ini Return on Asset, Current Ratio, Collateralized Asset tidak memiliki pengaruh terhadap Dividend Payout Ratio, tetapi Debt To Equity Ratio, Firm Size memiliki pengaruh terhadap Dividend Payout Ratio.

Kata kunci: Dividend payout ratio, return on asset, current ratio, debt to equity ratio, firm size, collateralized asset

\section{PENDAHULUAN}

Pasar modal merupakan tempat bagi para investor untuk melakukan aktivitas investasi. Pasar modal merupakan pasar untuk berbagai instrumen keuangan jangka panjang yang bisa diperjualbelikan, baik surat utang (obligasi), ekuiti (saham), reksa dana, instrumen derivatif maupun instrumen lainnya. (Sundjaja dan Barlian 2013, 479). Harapan dalam berinvestasi adalah mendapatkan keuntungan di masa yang akan datang. Pada dasarnya, tujuan utama seorang investor menanamkan modalnya adalah untuk memperoleh pendapatan atau tingkat pengembalian investasi (return) maupun pendapatan dari selisih harga jual saham terhadap harga belinya (capital gain). Investor yang tidak bersedia mengambil risiko lebih menginginkan pembagian dividen daripada capital gain.

Pembagian dividen dianggap lebih aman oleh investor karena dapat meminimalisir 
ketidakpastian daripada memperoleh capital gain. Dividen adalah pembagian sisa laba bersih perusahaan yang didistribusikan kepada pemegang saham atas persetujuan rapat umum pemegang saham (Darmadji dan Fakhruddin 2012,140). Dividen dibagikan perusahaan kepada investor berdasarkan kebijakan dividen yang diputuskan oleh perusahaan. Kebijakan dividen merupakan bagian dari keputusan pendanaan.

Dividend Payout Ratio yaitu indikator dari kebijakan dividen suatu perusahaan yang dapat menunjukkan persentase laba perusahaan yang dibayarkan kepada pemegang saham biasa perusahaan berupa dividen tunai. Dividend payout ratio rasio ini mengukur berapa besar bagian laba bersih setelah pajak yang dibayarkan sebagai dividen kepada pemegang saham, semakin besar rasio ini berarti semakin sedikit bagian laba yang ditahan untuk membelanjai investasi yang dilakukan perusahaan (Sudana 2015,26). Objek yang digunakan dalam penelitian ini adalah perusahaan sub sektor makanan dan minuman. Alasan pertama peniliti melakukan pertimbangan earning per share (EPS) di BEl periode 2011-2018 dimana EPS terbesar dimiliki oleh sektor Consumer Goods. Pertimbangan selanjutnya yang menjadi alasan peneliti melakukan penelitian di sub sektor makanan dan minuman dengan melihat laju pertumbuhan industri pengolahan non-migas dari tahun 20112018 memiliki persentase besar dan tidak pernah mengalami minus diantara industri nonmigas lainnya. Pertimbangan ketiga yang menjadi alasan peneliti memilih objek sub sektor industri makanan dan minuman dengan melihat investasi PMDN 20122017 terbesar diantara sektor lainnya, data diambil Kementrian Perdagangan (KEMENDAG). Dipilihnya periode penelitian 2011-2018 dikarenakan data di BEI pada periode tersebut mendukung untuk dilakukan penelitian dengan jumlah sampel yang diperoleh peneliti sebanyak 56 perusahaan yang merupakan jumlah sampel yang optimum.
Penelitian ini merupakan replikasi dari penelitian sebelumnya Yurinawati dan Andayani (2017).

Rumusan Masalah Berdasarkan latar belakang masalah diatas dapat dirumuskan permasalahan yang akan di teliti adalah: Apakah terdapat pengaruh Return on Asset, Current Ratio, Debt to equity ratio, Firm Size, Collateralized Assets terhadap Dividend Payout Ratio pada perusahaan makanan dan minuman yang terdaftar di BEl periode 2011-2018? Tujuan Penelitian Berdasarkan rumusan masalah, tujuan penelitian adalah untuk untuk mengetahui pengaruh Return on Asset, Current Ratio, Debt to equity ratio, Firm Size, Collateralized Assets terhadap Dividend Payout Ratio pada perusahaan makanan dan minuman yang terdaftar di BEI periode 2011-2018.

\section{Signalling Theory}

Signalling Theory Menurut Gittman and Zutter $(2015,586)$ : "Signaling theory,a financing action by management that is believed to reflect its view of the firm's stock value; generally, debt financing is viewed as a positive signal that management believes the stock is "undervalued," and a stock issue is viewed as a negative signal that management believes the stock is "overvalued". Dari definisi diatas disimpulkan bahwa pentingnya informasi bagi investor untuk menggambarkan kondisi perusahaan, agar investor bisa mengetahui kondisi perusahaan ,dimana informasi tentang keputusan perusahaan, merupakan signal atau kondisi terhadap keadaan perusahaan itu. Informasi perusahaan penting untuk investor menilai prospek kinerja perusahaan, untuk menjadi pertimbangan investor untuk menginvestasikan dananya.

Bird In the hand Theory Menurut Gitman dan Zutter $(2015,627)$ "Investors see current dividends as less risky than future dividends or capital gains". Atas beberapa pendapat di atas maka dapat disimpulkan bahwa Bird in The Hands Theory merupakan teori yang menyatakan bahwa kebijakan dividen dapat 
mempengaruhi nilai perusahaan atau biaya modal. Hal ini karena investor lebih menyukai menerima kas tunai daripada capital gain. Pembagian dividen dianggap lebih aman oleh investor karena dapat meminimalisir ketidakpastian daripada memperoleh capital gain.

Dividend Payout Ratio Menurut Gitman dan Zutter $(2015,628)$, "Dividend policy is the firm's plan of affection to be followed whenever it makes a dividend decision". Kebijakan dividen merupakan keputusan untuk menentukan berapa banyak dividen yang harus dibagikan kepada pemegang saham. Indikator yang digunakan untuk mengukur Kebijakan Dividen adalah Dividend Payout Ratio (DPR). Rasio pembayaran dividen merupakan rasio yang mengukur perbandingan dividen terhadap laba perusahaan.(Darmadji dan Fakhruddin, 2012, 159). Menurut Gitman dan Zutter (2015:630) "Dividend Payout Ratio indicates the percentage of each dollar earned that a firm distributes to the owner in the form of cash. Its calculated by dividing the firm cash dividend per share by its earning per share." Dengan demikian, dapat disimpulkan bahwa Dividend Payout Ratio merupakan persentase laba yang diperoleh perusahaan dan didistribusikan dalam bentuk dividen tunai kepada pemegang saham. Serta untuk mengukur besaran dividen yang akan dibagikan kepada pemegang saham.

Return on Asset terhadap Dividend Payout Ratio Menurut Gittman dan Zutter (2015:130), "Return On Assets measures the overall effectiveness of management in generating profit with its available assets". Berdasarkan uraian diatas dapat disimpulkan Return on Asset adalah salah satu bentuk rasio untuk mengukur kemampuan perusahaan dalam menghasilkan laba bersih atas penggunaan aset dari perusahaan. Berdasarkan hasil penelitian yang dilakukan Yurinawati dan Andayani (2017) menyatakan bahwa Return on Assets berpengaruh positif terhadap Dividend Payout Ratio, Namun menurut penelitian yang dilakukan oleh Sari dan Sudjarni (2015), Yudha et al.
(2017) menyatakan bahwa Return on Assets tidak berpengaruh terhadap Dividend Payout Ratio.

$\mathrm{H}_{1}$ Terdapat pengaruh Return on Asset terhadap Dividend Payout Ratio.

Current Ratio terhadap Dividend Payout Ratio Menurut Gitman dan Zutter $(2015,119)$, "Current Ratio is a measure of liquidity calculated by dividing the firm's current assets by its current liabilities". Berdasarkan pengertian diatas disimpulkan bahwa current ratio memiliki kemampuan perusahaan membayar kewajiban jangka pendek dengan menggunakan aset lancar yang dimilikinya. Berdasarkan hasil penelitian yang dilakukan Yurinawati dan Andayani (2017) menyatakan bahwa Current Ratio tidak berpengaruh terhadap Dividend Payout Ratio, Namun menurut penelitian yang dilakukan oleh Rindasari (2018), menyatakan bahwa Current Ratio berpengaruh positif terhadap Dividend Payout Ratio,Tetapi berbeda dengan penelitian Baramuli (2016) menyatakan bahwa Current Ratio berpengaruh negatif terhadap Dividend Payout Ratio.

$\mathrm{H}_{2}$ Terdapat pengaruh Current Ratio terhadap Dividend Payout Ratio.

Debt to Equity Ratio terhadap Dividend Payout Ratio Menurut Gitman and Zutter $(2017,147)$ debt to equity ratio measure the relative proportion of total liabilities to common stock equity used to finance the firm assets.as with debt ratio,a higher debt to equity ratio means that the firm uses more financial leverage. Dengan demikian, debt to equity ratio menggambarkan perbandingan hutang dengan ekuitas dalam pendanaan perusahaan dan menunjukkan kemampuan modal sendiri perusahaan tersebut untuk memenuhi seluruh kewajibannya. Semakin rendah rasio ini, semakin tinggi pendanaan perusahaan yang disediakan oleh pemegang saham. Berdasarkan hasil penelitian yang dilakukan Yurinawati dan Andayani (2017) dan Helmina dan Hidayah (2017) menyatakan bahwa Debt to Equity ratio 
tidak berpengaruh terhadap Dividend Payout Ratio, Namun menurut penelitian yang dilakukan oleh Rindasari (2018), menyatakan bahwa Debt to Equity Ratio berpengaruh negatif terhadap Dividend Payout Ratio. Tetapi berbeda dengan hasil penelitian Samrotun (2015) menyatakan bahwa Debt to Equity Ratio berpengaruh positif terhadap Dividend Payout Ratio.

$\mathrm{H}_{3}$ Terdapat pengaruh Debt to Equity Ratio terhadap Dividend Payout Ratio.

Firm Size terhadap Dividend Payout Ratio Menurut Kartikasari dan Merianti (2016, 410) "The size of company may be measured by total assets, total sales, number of employees, and market capitalization, The bigger a company, the more easily it garners outside capital." Dengan demikian, firm size merupakan alat untuk mengukur besar kecilnya perusahaan yang dapat diukur dari total aset yang dimilikinya. Semakin besar ukuran perusahaan akan memperoleh keuntungan yang lebih besar untuk memperoleh modal. Berdasarkan hasil penelitian yang dilakukan Yurinawati dan Andayani (2017), Stevanius dan Yap (2017), Helmina dan Hidayah (2017) menyatakan bahwa Firm Size tidak berpengaruh terhadap Dividend Payout Ratio, Namun menurut penelitian yang dilakukan oleh Yudha et al. (2017), menyatakan bahwa Firm Size berpengaruh positif terhadap Dividend Payout Ratio. Tetapi berbeda dengan hasil penelitian Sari et al. (2016) menyatakan bahwa Firm Size berpengaruh negatif terhadap Dividend Payout Ratio.

$\mathrm{H}_{4}$ Terdapat pengaruh Firm Size terhadap Dividend Payout Ratio.

Collateralized Asset terhadap Dividend Payout Ratio Menurut Ardiyos $(2010,198)$, menjelaskan bahwa Collateralize menjanjikan aktiva-aktiva untuk menjamin suatu utang. Aktiva-aktiva tersebut akan diserahkan apabila peminjam tidak mampu melunasi utang (default) berdasarkan syarat-syarat dan kondisi yang telah ditentukan dalam perjanjian utang. Berdasarkan pendapat diatas, maka dapat disimpulkan bahwa aset tetap yang semakin banyak dimiliki oleh perusahaan dapat dijadikan sebagai jaminan perusahaan untuk pemberi pinjaman sebagai jaminan. Berdasarkan hasil penelitian yang dilakukan Yurinawati dan Andayani (2017), Helmina dan Hidayah (2017) menyatakan bahwa Collateralized Assets tidak berpengaruh terhadap Dividend Payout Ratio, Namun menurut penelitian yang dilakukan oleh Mangasih dan Asandimitra (2017), menyatakan bahwa Collateralized Assets berpengaruh positif terhadap Dividend Payout Ratio.

$\mathrm{H}_{5}$ Terdapat pengaruh Collateralized Asset terhadap Dividend Payout Ratio.

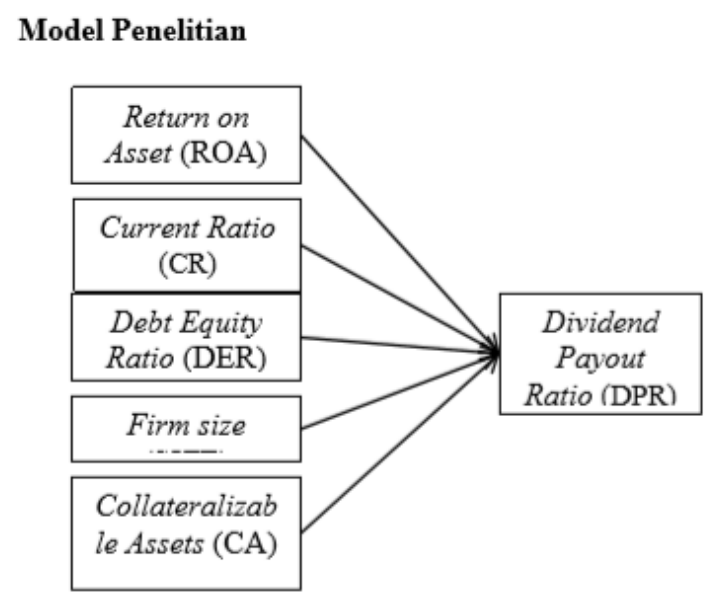

\section{METODE PENELITIAN}

Metode Pemilihan Sampel Objek yang dipilih pada penelitian ini adalah perusahaan makanan dan minuman yang terdaftar di BEI periode 2011-2018. Metode purposive sampling yang digunakan dalam teknik pemilihan sampel , purposive sampling yang merupakan teknik penentuan sampel dengan pertimbangan khusus sehingga layak dijadikan sampel (Neolaka 2014:96).

Beberapa kriteria yang dipilih untuk memperoleh sampel sebagai berikut : Perusahaan Makanan dan Minuman yang tercatat pada Bursa Efek Indonesia (BEI) secara 
beruturut-turut selama periode 2011-2018, Perusahaan makanan dan minuman yang membagikan dividen secara berturut-turut selama periode tahun 2011-2018, Perusahaan makanan dan minuman yang mempublikasikan laporan keuangan secara lengkap selama periode 2011-2018.

Teknik Pengumpulan Data Penelitian ini diperoleh datanya dari laporan keuangan perusahaan yang telah dipublikasikan. maka pengumpulan data yang digunakan adalah sumber data sekunder. Data sekunder merupakan data dari sumber lain (Neolaka, 2014,8). Penelitian ini meggunakan jenis data sekunder. Data sekunder dalam penelitian ini berupa laporan keuangan, berupa mencari dokumen laporan tahunan (annual report) periode tahun 2011 - 2018 dari www.idx.co.id, Badan Pusat Statistik, Kementrian Perdagangan.

Return on Asset (ROA) Return on Asset (ROA) merupakan rasio yang menggambarkan efisiensi dana yang digunakan dalam perusahaan. Rasio ini membandingkan antara laba bersih dengan total aset. Menurut Yurinawati dan Andayani $(2017,8)$. Current ratio (CR) Current ratio merupakan rasio untuk mengukur kemampuan perusahaan dalam membayar kewajiban jangka pendek atau utang yang segera jatuh tempo pada saat ditagih secara keseluruhan Menurut Widya dan Andayani (2017). Debt to equity ratio (DER) Debt to equity ratio merupakan menunjukkan kemampuan modal sendiri perusahaan tersebut untuk memenuhi seluruh kewajibannya. Rasio ini menggambarkan perbandingan antara total utang dengan total modal perusahaan. Menurut Widya dan Andayani (2017). Firm size Firm size merupakan rasio ini merupakan salah satu alat untuk mengukur besar kecilnya perusahaan. Yurinawati dan Andayani (2017,9).Alat ukur yang digunakan adalah Size dengan menggunakan rumus. Collateralized assets (CA) Collateralized assets (CA) merupakan besarnya aset yang dijaminkan untuk menjamin pinjaman kepada kreditor. Menurut Yurinawati dan Andayani $(2017,9)$.

\section{HASIL DAN PEMBAHASAN}

Untuk melihat hasil dari data penelitian digunakan statistic deskriptif untuk menganalisa variabel DPR, ROA, CR, DER, FS dan Coolinearity dari 56 data penelitian.

\section{Statistik Deskriptif}

Statistik deskriptif seluruh variabel yang digunakan dalam penelitian disajikan pada tabel 1 sebagai berikut:

Tabel 1

Hasil Pengolahan Statistik Deskriptif

\begin{tabular}{lcccccc}
\hline & DPR & ROA & CR & DER & FS & COL \\
\hline Mean & 0.320008 & 0.114439 & 2.202210 & 0.750709 & 29.20835 & 0.319542 \\
\hline Median & 0.255170 & 0.102226 & 2.307203 & 0.775380 & 29.09331 & 0.261235 \\
\hline Maximum & 0.880084 & 0.337375 & 3.065345 & 1.280577 & 32.20096 & 0.783977 \\
\hline Minimum & 0.030330 & 0.027298 & 1.048854 & 0.214410 & 26.09035 & 0.149008 \\
\hline Std. Dev. & 0.212376 & 0.071329 & 0.564353 & 0.359832 & 1.763034 & 0.150723 \\
\hline Observation & 56 & 56 & 56 & 56 & 56 & 56 \\
\hline
\end{tabular}


Tabel 2

Uji t

\begin{tabular}{crrrr}
\hline Variabel & Coefficient & \multicolumn{1}{c}{ Std. Error } & \multicolumn{1}{c}{ t-Statistic } & \multicolumn{1}{c}{ Prob. } \\
\hline C & -2.599587 & 1.470372 & -1.767980 & 0.0840 \\
\hline ROA & -0.726952 & 0.572946 & -1.268796 & 0.2112 \\
\hline CR & -0.084634 & 0.065707 & -1.288050 & 0.2045 \\
\hline DER & -0.293534 & 0.111129 & -2.641372 & 0.0114 \\
\hline FS & 0.109637 & 0.051689 & 2.121069 & 0.0396 \\
\hline COL & 0.648493 & 0.369220 & 1.756386 & 0.0860 \\
\hline
\end{tabular}

Sumber: Hasil Pengolahan Data dengan Eviews 9

Pengaruh Return on Asset terhadap Dividend Payout Ratio Menurut tabel 2, tStatistik memiliki nilai -1.268796 yang lebih kecil dari t-tabel 2.009, maka t-statistik terletak di daerah $\mathrm{Ha}$ ditolak. Di samping itu, didukung oleh hasil nilai probabilitas ( $p$-value) 0.2112 yang lebih besar dari alpha 0,05. Dengan demikian, dapat disimpulkan bahwa Return on Asset (ROA) tidak mempengaruhi terhadap Dividen Payout Ratio (DPR) pada sektor makanan dan minuman yang terdaftar di BEI periode 20112018. Hasil ini konsisten dengan penelitian sebelumnya konsisten dengan penelitian Sari dan Sudjarni (2015) dan Yudha et al. (2017). Tetapi, hasil ini tidak konsisten dengan penelitian sebelumnya Yurinawati dan Andayani (2017) yang menunjukan bahwa Return on Asset berpengaruh positif terhadap Dividend Payout Ratio.

Pengaruh Current Ratio terhadap Dividend Payout Ratio Menurut tabel 2, tStatistik memiliki nilai -1.288050 yang lebih kecil dari t-tabel 2009, maka t-statistik terletak di daerah Ha ditolak. Di samping itu, didukung oleh hasil nilai probabilitas ( $p$-value) 0.2045 yang lebih besar dari alpha 0,05. Dengan demikian, dapat disimpulkan bahwa Current Ratio (CR) tidak mempengaruhi Dividen Payout Ratio (DPR) pada sektor makanan dan minuman yang terdaftar di BEI periode 2011-2018. Hasil ini konsisten dengan penelitian sebelumnya Yurinawati dan Andayani (2017). Tetapi hasil ini tidak konsisten dengan penelitian yang dilakukan oleh Rindasari (2018), menyatakan bahwa Current Ratio berpengaruh positif terhadap Dividend Payout Ratio, Tetapi berbeda dengan penelitian Baramuli (2016) menyatakan bahwa Current Ratio berpengaruh negatif terhadap Dividend Payout Ratio.

Pengaruh Debt to Equity Ratio terhadap Dividend Payout Ratio Menurut tabel 2, tStatistik memiliki nilai -2.641372 yang lebih kecil dari t-tabel 2.009, maka t-statistik terletak di daerah Ha diterima. Di samping itu, didukung oleh hasil nilai probabilitas ( $p$-value) 0.0114 yang lebih kecil dari alpha 0,05. Dengan demikian, dapat disimpulkan bahwa Debt to Equity Ratio (DER) mempengaruhi Dividen Payout Ratio (DPR) pada sektor makanan dan minuman yang terdaftar di BEI periode 20112018. Hasil ini konsisten dengan penelitian sebelumnya Rindasari (2018), Tetapi hasil ini tidak konsisten dengan penelitian yang dilakukan Samrotun (2015) menyatakan bahwa Debt to Equity Ratio berpengaruh positif terhadap Dividend Payout Ratio. Tetapi berbeda dengan penelitian yang dilakukan Yurinawati dan Andayani (2017) yang menunjukan bahwa Current Ratio tidak berpengaruh terhadap Dividend Payout Ratio.

Pengaruh Firm Size terhadap Dividend Payout Ratio Menurut tabel 2, t-Statistik memiliki nilai 2.121069 yang lebih besar dari t-tabel 2.009, maka t-statistik terletak di daerah $\mathrm{Ha}$ diterima. Di samping itu, didukung oleh hasil nilai probabilitas ( $p$-value) 0.0396 yang lebih kecil dari alpha 0,05. Dengan demikian, dapat disimpulkan bahwa Firm Size (FS) mempengaruhi Dividen Payout Ratio (DPR) pada sektor makanan dan minuman yang 
terdaftar di BEl periode 2011-2018. Hasil ini konsisten dengan penelitian sebelumnya Yudha et al. (2017). Tetapi hasil ini tidak konsisten dengan penelitian Sari et al. (2016) menyatakan bahwa Firm Size berpengaruh negatif terhadap Dividend Payout Ratio. Tetapi, berbeda dengan penelitian Yurinawati dan Andayani (2017) yang menunjukan bahwa Firm Size tidak berpengaruh terhadap Dividend Payout Ratio.

Pengaruh Collateralized Asset terhadap Dividend Payout Ratio Menurut tabel 2, tStatistik memiliki nilai 1.756386 yang lebih kecil dari t-tabel 2.009, maka t-statistik terletak di daerah Ha ditolak. Di samping itu, didukung oleh hasil nilai probabilitas ( $p$-value) 0.0860 yang lebih besar dari alpha 0,05. Dengan demikian, dapat disimpulkan bahwa Collateralized Asset (COL) tidak mempengaruhi Dividen Payout Ratio (DPR) pada sektor makanan dan minuman yang tercatat di BEI periode 2011-2018. Hasil ini konsisten dengan penelitian sebelumnya Yurinawati dan Andayani (2017) dan Helmina dan Hidayah (2017). Tetapi, hasil ini tidak konsisten dengan penelitian Mangasih dan Asandimitra (2017) yang menunjukan bahwa Collateralized Asset berpengaruh positif terhadap Dividend Payout Ratio.

\section{PENUTUP}

Berdasarkan hasil analisis dan pembahasan, dengan jumlah sampel 7 perusahaan makanan dan minuman yang tercatat di Bursa Efek Indonesia (BEI) periode 20112018. peneliti menyimpulkan hasil penelitian sebagai berikut: Return on Asset, Current Ratio, Collateralized Asset tidak terdapat pengaruh, tetapi Debt to Equity ratio, Firm Size terdapat pengaruh terhadap Dividend Payout Ratio.

Keterbatasan dalam penelitian ini yaitu hanya terbatas pada perusahaan makanan dan minuman, sehingga jumlah sampel yang digunakan relatif sedikit. Variabel independen yang digunakan hanya terbatas pada 5 variabel independen yaitu Return on Assets,Current Ratio, Debt to Equity ratio, Firm Size, Collateralized Assets, dalam menganalisis Dividend Payout Ratio. Penelitian ini hanya mengambil waktu 8 tahun dari periode 2011 sampai tahun 2018. Data mungkin tidak mencerminkan sepenuhnya kondisi perusahaan dalam jangka panjang.

Saran bagi penelitian selanjutnya yaitu menggunakan objek sektor lain yang memiliki jumlah perusahaan yang lebih banyak, sehingga dapat memilih sampel yang banyak. Menambah variabel independen lain yang dianggap memiliki pengaruh terhadap Dividend Payout Ratio. Memperpanjang periode penelitian dapat digunakan sebagai pertimbangan untuk mendapatkan hasil yang lebih akurat.

\section{REFERENCES:}

Ardiyos. 2010. Kamus Besar Akuntansi. Jakarta: Citra Harta Prima.

Baramuli, Dedy Natanael. 2016. Pengaruh Likuiditas Dan Profitabilitas Terhadap Devidend Payout Ratio Pada Top Bank Di Indonesia (BRI, Bank Mandiri, BNI, Dan BCA). Jurnal Berkala IImiah Efisiensi, 16(3).

Darmadji, Tjiptono., \& Hendy M. Fakhruddin. 2012. Pasar Modal di Indonesia. Edisi ketiga. Jakarta: Salemba Empat Gitman, Lawrence J. dan Chad J. Zutter. 2015. Principles of Managerial Finance, Fourteenth Edition. United States of America: Pearson Education.

Helmina, Monica Rahardian Ary Helmina., \& Raudhatul Hidayah. 2017 . Pengaruh Institutional Ownership ,Collateralizable Assets, Debt to Total Assets, Firm Size Terhadap Dividend Payout Ratio. Jurnal IImiah Ekonomi Bisnis, 3(1).

Kartikasari, Dwi \& Marisa Merianti. 2016. The Effect of Leverage and Firm Size to Profitability of Public Manufacturing Companies in Indonesia.. International Journal of Economics and Financial Issues. 
Kasmir. 2016. Analisis Laporan Keuangan. Jakarta: Rajawali Pers.

Mangasih, Grevia Violetta., \& Nadia Asandimitra. 2017 . Pengaruh Insider Ownership, Institutional Ownership, Dispersion of Ownership, Collateralizable Assets, Board Independence terhadap Kebijakan Dividen pada Sektor, Jurnal IImu Manajemen, 5(3).

Neolaka, Amos. 2014. Metode Penelitian dan Statistik Cetakan Pertama: Untuk Perkuliahan Mahasiswa Sarjana dan Pasca Sarjana. Bandung: PT Remaja Rosdakarya.

Rindasari, Afira Dwi. 2018 . Pengaruh Profitabilitas, Likuiditas, Rentabilitas Modal Sendiri, Debt to Equity Ratio, dan Net Profit Margin terhadap Dividend Payout Ratio Pada Peruahaan Manufaktur. Jurnal Akutansi Universitas Yogyakarta, 7(1).

Samrotun, Yuli Chomsatu. 2015. Kebijakan Dividen dan Faktor Faktor yang Mempengaruhinya. Jurnal Paradigma 13(01), 92-103.

Sari, Komang Ayu Novita., \& Luh Komang Sudjarni. 2015 . Pengaruh Likuiditas, Leverage, Pertumbuhan Perusahaan, dan Profitabilitas terhadap Kebijakan Dividen pada Perusahaan pada Manufaktur. E-Jurnal Manajemen Unud, 4(10).

Sari, Marvita Renika., Abrar Oemar., Rita Andini. 2016. Pengaruh Pertumbuhan Perusahaan, Ukuran Perusahaan, Earning Per Share, Current Ratio, Return On Equity Dan Debt Equity Ratio Terhadap Kebijakan Dividen. Journal of Accounting, 2(2).

Sjahrial, Dermawan. 2014. Manajemen Keuangan Lanjutan. Edisi Revisi. Jakarta: Mitra Wacana Media.

Stevanius., Steven Yap. 2017. Pengaruh Debt To Asset Ratio, Rasio Kas, Size, Return On Asset, Growth, dan Kepemilikan Institusional Terhadap Dividend Payout Ratio Pada Sektor Perbankan, Jurnal Bisnis dan Akuntansi, 19(1): 117-128.

Sudana, I Made. 2015. Manajemen Keuangan Perusahaan Teori dan Praktik, Edisi 2. Jakarta: Penerbit Erlangga. Sugiyono. 2017. Metode Penelitian Kuantitatif dan Kualitatif. Bandung: CV. Alfabeta.

Sundjaja, Ridwan S., \& Inge Barlian., Dharma Putra Sundjaja. 2013. Manajemen Keuangan 1, Ed.8. Jakarta: Literata Lintas Media.

Yurinawati, Widya. Andayani. 2017. Pengaruh Kinerja Keuangan, Ukuran Perusahaan, dan Jaminan Aset Terhadap Kebijakan Dividen. Jurnal Bisnis dan Akuntansi, 6(9). 